\section{COMMUNITY EMPOWERMENT BASED ECOTOURISM VILLAGE DEVELOPMENT STRATEGY IN THE NEW NORMAL ERA IN SABANG REGENCY}

\author{
${ }^{1 * H i l m i, ~}{ }^{2}$ Dy Ilham Satria \\ ${ }^{1,2}$ Faculty of Economics and Business, Malikussaleh University \\ *Correspondence Author : dyilham@unimal.ac.id
}

\begin{abstract}
This study aims to determine the resources that have the potential to be developed into ecotourism in the coastal area of Sabang Regency, to determine the physical and social carrying capacity of the coastal area of Sabang to tourism activities, to formulate a model of ecotourism development based on Community Empowerment that is appropriate for managing the coastal area of Weh Island. Qualitative descriptive methods were used in determining the physical carrying capacity, surveys of community perceptions with respondents of local resident Sabang and surveys of visitor satisfaction to obtain information and analyze tourism potential in the City of Sabang and feasibility for ecotourism development. The results obtained from natural resources of marine tourism have the potential to be developed into ecotourism in the coastal area of the city of Sabang, especially in Iboh Beach, Rubiah Island, and Sumur Tiga Beach. The physical and social support capacity of the coastal area of Sabang for tourism activities is very good, so it deserves to be a national and international mainstay tourism with the concept of empowering the existing community by continuing to promote, improve and add tourism supporting infrastructure, and add national and international events in Sabang.
\end{abstract}

Keywords: Development Strategy, Ecotourism Village, Tourism Awareness Community Empowerment

\section{INTRODUCTION}

Since Covid-19 hit the world, especially Indonesia, the province of Aceh has not been spared the impact of Covid-19. The tourism sector, which has been predicted as the second largest source of foreign exchange contribution for Indonesia, has been paralyzed. Regulations on social distancing and instructions for activities at home have made the tourism sector sluggish. In fact, the sluggishness was felt before Indonesia announced that there were positive corona patients in early March 2020. Numbers of stimuli prepared by the government to revive the tourism sector were unable to stem the negative impact of corona. Many tourist attractions are closed, which means there is no income for tourism sector businesses.

Covid-19 has devastated the tourism industry, including the coastal area of the Sabang area. Sabang area has good potential to be developed as a leading tourist attraction. Sabang offers a number of tourism potentials, such as Iboih beach, Sumur Tiga beach, Pasir Putih beach, Anoi Itam beach, Pantai Kasih beach with clear blue sea, fresh water lake called Aneuk Laot lake, hot springs at Mount Merapi Jaboi, a number of forts left over from the World War II, and the 0 (Zero) Kilometer Point Monument. The small islands also offer numbers of potentials, including snorkeling and diving locations such as Rubiah Island which has unspoiled underwater views decorated with coral reefs and colorful marine fish.

For this reason, tourism development in the Sabang area must be carried out wisely, taking into account the pre-existing environmental and socio-cultural conditions. The form of tourism must be chosen in accordance with the characteristics of the existing area. One form of special tourism activities that can be developed in Sabang regency area is ecotourism. Ecotourism is a tourism development concept that prioritizes harmony between tourism economic goals (welfare of local communities) and conservation/environment protection goals. 
Ecotourism was first introduced by the organization The Ecotourism Society (1990) as follows: "Ecotourism is a form of travel to natural areas carried out with the aim of conserving the environment and preserving the life and welfare of local residents. The term "ecotourism" can be interpreted as a trip by a tourist to remote areas with the aim of enjoying and learning about the nature, history and culture of an area, where the tourism pattern helps the local community's economy and supports nature conservation (Ceballos-Lascurain, 1996 in the Directorate of Tourism Products, 2010) International Ecotourism Society (TIES, 2010). 2000) defines ecotourism as a responsible nature tourism trip by conserving the environment and improving the welfare of local communities (Fandeli, C., 2000;Damanik and Weber, 2006).

But on the other hand, the massive exploitation of coastal resources, especially in the efforts to expand the designated area, can spur economic growth. In terms of the availability of sustainable resources, development that does not pay attention to the sustainability aspect will reduce the ability of coastal resources themselves to support service functions for the balance of ecosystems in coastal areas in the long term. Neglect of coastal area spatial planning, destructive use, unclear policies in coastal area resource management, and low community involvement will lead to less than optimal management of coastal area resources. (Tulungen, et al., 2003).

Broadly speaking, the symptoms of environmental damage that threaten the sustainability of coastal and marine resources in Indonesia include: (1) pollution, (2) physical degradation of habitats, (3) overuse of natural resources, (4) coastal abrasion, (5) area conversion. protection for other development purposes, and (6) natural disasters (Dahuri, et al., 2008). In addition to environmental damage, coastal and marine areas also face problems of conflict of interest and utilization. There are two main types of conflicts related to coastal areas, namely: (1) conflicts between direct users of resources, or between direct users and indirect/potential beneficiaries (such as environmental groups,

Based on the above phenomenon, a good management fund strategy is needed for ecotourism management. The strategy needed must pay attention to both, namely the environmental impact and the impact of community progress. Therefore we need an ecotourism development strategy based on community empowerment. This is in line with the results of research from Richardson (1991) in Wearing and Neil (2009) which states that in general ecotourism pays more attention to environmental impacts than general tourism, and promotes understanding and respect for culture, customs and the natural environment. The principle of the ecotourism pattern is to minimize negative impacts on the environment and local culture and be able to increase economic income for the community as well as conservation value. The application of ecotourism must be carried out carefully and carefully, starting from the planning, management and supervision processes (Kelkit, et al., 2010). Although ecotourism provides positive benefits for nature, it is important for managers to pay attention to possible adverse effects, which are included in planning and management strategies (Wearing and Neil, 2009). According to Damanik and Weber (2006), the ecotourism planning process goes through several stages, namely (1) Identification of the development of tourist visits, (2) Evaluation of the impact on the existence of the environment, (3) Identification of available tourist attractions and those that can be developed, (4) Identification of involvement of various stakeholders in management, (5) Identification of potential market segments and characteristics of their needs. management to supervision (Kelkit, et al., 2010). Although ecotourism provides positive benefits for nature, it is important for managers to pay attention to possible adverse effects, which are included in planning and management strategies (Wearing and Neil, 2009). According to Damanik and Weber (2006), the ecotourism planning process goes through several stages, namely (1) Identification of the development of tourist visits, (2) Evaluation of the impact on the existence of the environment, (3) Identification of available tourist attractions and those that can be developed, (4) Identification of involvement of various stakeholders in management, (5) Identification of potential market segments and characteristics of their needs. management to supervision (Kelkit, et al., 2010). Although ecotourism provides positive benefits for nature, it is important for managers to pay attention to possible adverse effects, which are included in planning and management strategies (Wearing and Neil, 2009). According to Damanik and Weber (2006), the ecotourism planning process goes through 
several stages, namely (1) Identification of the development of tourist visits, (2) Evaluation of the impact on the existence of the environment, (3) Identification of available tourist attractions and those that can be developed, (4) Identification of involvement of various stakeholders in management, (5) Identification of potential market segments and characteristics of their needs. it is important for managers to pay attention to possible adverse effects, which are included in planning and management strategies (Wearing and Neil, 2009). According to Damanik and Weber (2006), the ecotourism planning process goes through several stages, namely (1) Identification of the development of tourist visits, (2) Evaluation of the impact on the existence of the environment, (3) Identification of available tourist attractions and those that can be developed, (4) Identification of involvement of various stakeholders in management, (5) Identification of potential market segments and characteristics of their needs. it is important for managers to pay attention to possible adverse effects, which are included in planning and management strategies (Wearing and Neil, 2009). According to Damanik and Weber (2006), the ecotourism planning process goes through several stages, namely (1) Identification of the development of tourist visits, (2) Evaluation of the impact on the existence of the environment, (3) Identification of available tourist attractions and those that can be developed, (4) Identification of involvement of various stakeholders in management, (5) Identification of potential market segments and characteristics of their needs.

The development of coastal areas according to Khakhim, et al., (2008) must follow a pattern of sustainability and integration so that the utilization of these coastal areas does not harm each other. Sustainability means environmental integrity, improving the quality of life, and equity between generations, while integration means planning integration between national, provincial, regional and local levels as well as planning integration between sectors at each level of government, such as integration between the tourism sector and the fisheries sector. at the regional level, and so on. Integrated coastal area management is a coastal area management approach that involves two or more ecosystems, resources, and integrated utilization (development) activities in order to achieve sustainable coastal area development. In this case, integration contains three dimensions: sectoral, field of science, and ecological linkages (Dahuri, et al., 2008). Cicin-Sain (1998) explains that integrated coastal management is a dynamic and continuous process in making decisions on sustainable use, development and protection of coastal areas.

\section{IMPLEMENTATION METHOD}

This research is a qualitative descriptive study with the research stages: (1) research preparation, (2) initial observation, (3) problem identification, (4) activity objectives, (5) literature and field studies, (6) data collection and follow-up observations. , (7) Data sorting and data management, (8) Analysis of results and conclusions.

Research locations are all tourism objects in the coastal area of Sabang Regency, which is a field study by conducting direct observations and sourced from primary data and secondary data obtained in the field. The parameters measured from the research are development strategies, ecotourism villages, and empowerment of tourism-aware communities. The research design that will be used in this study includes the initial planning process, research implementation and data analysis which can be described in Figure.1 The conceptual framework is as follows:

Community Empowerment-Based

Ecotourism Village Development Strategy

1. Identify the development of tourist visits

2. evaluation of the impact on the existence of the environment 
3. Identification of tourist attractions that are available and which can be developed

\begin{tabular}{|ll|}
\hline 4. & $\begin{array}{l}\text { identification of involvement of various } \\
\text { stakeholders in management }\end{array}$ \\
\hline 5. & $\begin{array}{l}\text { identification of potential market segments and } \\
\text { characteristics of their needs }\end{array}$ \\
\hline
\end{tabular}

6. identification of ecotourism village project investment development models

Figure 1. Conceptual Framework

Data collection techniques in this study used an interview system, focus group discussion (FGD) and also the distribution of questionnaires to analyze the required reports. Distribution of questionnaires designed using an attitude scale based on ranking so that the results of respondents' answers have an interval scale (Sekaran, 2009: 32). Questionnaires will be distributed to the people of the city of Sabang and visitors to the city of Sabang. In this study the research method used is descriptive qualitative method. The unit of analysis to be studied in this study is the Coastal Zone of Sabang regency, with a population of 18 villages with 60 respondents. Information analysis is carried out through several stages through the data collection stage, the data reduction stage and the relevant data categories,

\section{RESULT AND DISCUSSION}

\section{COMMUNITY EMPOWERMENT BASED DEVELOPMENT STRATEGY IN SABANG REGENCY}

The tourism sector that wants to be developed in Sabang is natural and marine tourism, because the Sabang area as an archipelago certainly supports the development of this tourism. The nature of Sabang is very beautiful and there are various flora and fauna that can be enjoyed by tourists. These natural resources are certainly one of the opportunities for the welfare of the people of Sabang in particular. Sabang's Locally-generated revenue can increase with the number of tourist visits to this islands. The things that have been done include improving facilities and infrastructure, of course this needs serious support from Sabang government. Maintenance or maintenance of existing facilities is also very necessary, and this also needs to be increased awareness for the society in Sabang. A beautiful place that always needs to be cared for and maintained for its sustainability. The beauty of nature and the sea has its own value for travelers or tourists, if we can maintain this then Sabang will have added value especially in the economic sector. Related parties in the City of Sabang have conducted training programs for the local residents of Sabang, including training in henna (decoration of henna for guests who come and visit in Sabang), which was recently carried out and the results were very optimal. This needs to be optimized and sustainable, especially for guests who come by cruise ship from outside (tourists). Things that are difficult to agree on are with the Sabang City Islamic Shari'a Service,

\section{FIELDS OF DEVELOPMENT THAT HAVE BEEN DONE IN SABANG REGENCY}

The Government of Sabang regency continues to try to urge businessman, such as hoteliers or inns to check the completeness of identity for any guests who stay overnight or rent hotels or lodging places, such as completeness of marriage books, ID cards and others, especially for local tourists and tourists. Wisnu (archipelago tourist) who is Muslim. This does not apply to non-Muslims (both overseas and non-Muslims in the archipelago). Rules like this have never been implemented by his 
party so far, even if there are only an appeal, from that also entrepreneurs in the hotel and lodging sector do not heed this appeal.

The people of Sabang are now aware that coral reefs must be maintained properly, because with the existence of coral reefs, people will visit Sabang to see and enjoy the very beautiful underwater scenery, which according to local people is rarely found in places/areas that are very popular. others in Indonesia. With so many people or tourists coming to Sabang, the people of Sabang will automatically increase their economy, how not, these tourists will need, eat, drink and various other needs. For the people of Sabang, especially related parties to be able to provide facilities and infrastructure to support the realization of the city of Sabang as a tourist city. Of course, if the Sabang area is part of the Aceh region, the desired tourism should also have Islamic nuances.

To go to Sabang, of course, both local (domestic) and international (international) tourists, they go through Banda Aceh to Ulee Lhee port, from Ule Lhee port to reach Sabang they can use several crossing fleets. Ideally, since at Ulee Lhee Harbor, tourists have felt the nuances of Islam/Islamic law, but what they found was less visible, both at the port and in the ferry fleet (ships). It is better to continue to be endeavored by the relevant parties to raise awareness to the public, especially the business management parties, whether it is a selling business, lodging (hotels), transportation services and others.

\section{DEVELOPMENT OF ECO-TOURISM BASED ON COMMUNITY EMPOWERMENT IN SABANG REGENCY}

The tourist areas of Iboih Beach, Rubiah Island, and Sumur Tiga Beach are main tourist attractions as tourist villages in Weh Island. Even though Sabang has enormous tourism potential, from the initial observations of the implementing team to the village, it was found that until 2021 the village had not received any guidance regarding the management of its tourist village. It was further discovered that currently the knowledge possessed by human resources is still limited, marked by the lack of knowledge possessed by the community in the village in managing their potential to develop tourism villages. This general description then made the research implementation team together with students to coordinate with relevant stakeholders, namely the Village Government, and community leaders in the three tourist attraction areas in order to find the best solution in an effort to develop tourist villages that are able to be competitive and contribute directly to village income and the welfare of its people, especially during the covid19 pandemic. Initial observations were made twice for the three tourist sites.

The first phase of observation was carried out in early July 2021 when the COVID-19 pandemic hit, and the Sabang area was in the PPKM level 3 category. The purpose of this observation is to obtain initial data from the Tourism Village in Sabang as an ecotourism village that is feasible to be developed further. Based on the results of observations, there were several problems that occurred on the trekking route at the three tourist sites, including:

1. The tourist attraction in the form of trekking routes has not been well laid out, even when observations were carried out at a number of points it was clear that the buildings and name signs had been damaged and needed to be reworked so that they could add aesthetic value to increase tourist visits.

2. Mapping and completeness of supporting buildings are not complete, such as related to clean and comfortable public toilets, garbage disposal sites are not available on average, no clear concept is found in managing the place and coupled with a lack of awareness of environmental cleanliness in the place.

3. There are not many buildings that can attract tourists such as selfie spots so that the existing infrastructure on the Tourism Village route needs to be improved to become a proper facility as an object of tourist visits by adding aesthetics.

4. Promotions and publications are still not maximized regarding the existence and existing facilities, so they are not widely known by the public or the general public. These two things are 
considered very important, considering that currently digital marketing is considered very effective by using social media as a marketing medium.

\section{CONCLUSION}

Based on the description of the discussion of the research results described above, it can be concluded that marine tourism natural resources have the potential to be developed into ecotourism in the coastal area of Sabang City, especially in Iboih Beach, Rubiah Island, and Sumur Tiga Beach. The physical and social carrying capacity of the coastal area of Sabang for tourism activities is very good, so it deserves to be a national and international mainstay tourism with the concept of empowering the existing community by continuing to promote, improve and add tourism supporting infrastructure, and add national and international events in the area Sabang.

\section{REFERENCES}

Bien A. 2006. Ecotourism Handbook I - A Simple User's Guide To Certification For Sustainable Tourism And Ecotourism. CESD. Washington DC.

Beatley, T., Brower, DJ, and Schwab, AK 2002. An Introduction To Coastal Zone Management (Second edition). Island Press. Washington DC.

Bookbinder, MP, et al. 1998. Ecoutorism's Support of Biodiversity Conservation. Conservation Biology, 12(6). 1399-1404.

Cicin-Sain, B., and Knecht, RW 1998. Integrated Coastal and Ocean Management: Concepts and Practices. Island Press. Washington DC.

Khakhim, N., et al. 2008. Analysis of Visual Preferences for Coastal Landscapes in the Special Region of Yogyakarta for Coastal Tourism Development Towards Sustainable Management of Coastal Areas. Geography Forum, 22(1):44-59.

Kelkit, A., Celik, S., and Esbah, H. 2010. Ecotourism Potential of Gallipoli Peninsula Historical National Park. Journal of Coastal Research, 26(3): 562-568.

Kothari, CR 2004. Research Methodology: Methods and Techniques. Second Revised Edition. New Delhi: New Age International Publisher.

Tuwo, A. 2011. Coastal and Marine Ecotourism Management; Ecological, Socio-Economic, Institutional, and Regional Facilities Approach. International Brilliant. Surabaya.

Wang, H., and Shao, S. 2009. Study on the Eco-tourism Environment Protection Based on the External Theory. Asian Social Science, 5(1): 13-17.

Wishnutama. 2020. Fall due to corona covid 19 Menparekraf is still preparing a solution https://www.liputan6.com/lifestyle/read/4209455/sector-tourism-nearly, quoted on July 022020. 